\title{
Asia in the Russian Imagination
}

\author{
JANE F. HACKING, JEFFREY S. HARDY, \\ AND MATTHEW P. ROMANIELLO
}

$\mathrm{T}$ his special issue of Sibirica is devoted to exploring Russia's complicated relationship with Asia. Along with an edited volume (Russia in Asia: Imaginations, Interactions, and Realities, forthcoming), it is an outgrowth of the "Asia in the Russian Imagination" conference that was held at the University of Utah in March 2018. This conference brought together an interdisciplinary body of scholars from the United States, Canada, and Russia to discuss how Russians imagined and interacted with the peoples of Eurasia. Chronologically this conversation spanned the Russian Empire, Soviet Union, and post-Soviet Russia, and included not just the geography and peoples possessed by Russia but also the bordering states of Japan, China, and the Ottoman Empire. This is certainly not a new line of inquiry, but there is still much to be understood about these complex relationships, both real and imagined.

The four articles in this issue are all chronologically rooted in the post-Petrine Russian Empire. The first, by Gwyn Bourlakov, investigates the use of Siberian convents as places of exile and incarceration in the mid-to-late eighteenth century. Designated as a place to hold elite noblewomen, Dalmatov Vvedenskii Convent in Western Siberia stood "far off" from European Russia, serving as both a physical and psychological place of distant separation. Such convents also held local women from the complex Siberian frontier, often for spiritual crimes such as the heresy of Old Belief. The abbesses of the convent were charged with acting as mediators between state agents and the Russian cultural sphere, on the one hand, and the exiled inmates on the other. In particular, they were called to impose discipline on their prisoners-both in a secular and spiritual sense. In this way women in positions of ecclesiastical power were important agents of empire in Siberia.

The subsequent three articles by Tatiana Saburova, Marisa Karyl Franz, and Zachary Hoffman all deal with visual representations of Asia that were produced in the Russian Empire toward the end of the long nineteenth century. Saburova's work centers on a host of political exiles in the late 1800s in Siberia, who became photographers as a way to 
earn a living and to engage in an at-once cultural and scientific pursuit. In addition to portraits, they captured the landscapes of Siberia. They also participated in various ethnographic expeditions, thereafter selling their photographs in European Russia as "views and types" collections or submitting them to museums and scientific societies. The "types" here were ethnographic portraits of the various peoples of Siberia and Mongolia, used to classify people according to their evolutionary development. This anthropological photography was not unique to Russia, Saburova notes but was common across European-based empires. It served to exoticize the "east" and to define Russian cultural superiority as a justification for empire. The "views" of both the magnificent natural beauty of Siberia and the hard labor performed by exiles helped European Russians imagine a wild part of Russia that was slowly being incorporated into the imperial whole.

Marisa Karyl Franz's article on ethnographic descriptions of Siberian and Central Asian shamanism in St. Petersburg's famous Kuntskamera museum continues this discussion of how Russians imagined Asia. Focusing on guidebooks from 1891 and 1904, Franz demonstrates how whereas initially Siberian materials were categorized as Russian, by 1904 they had been classified as Asian, a geospatial identity defined by the religious practice of shamanism (as opposed to the Buddhism of East Asia). Late imperial ethnographers tasked with collecting and categorizing the museum's collection acknowledged variations within this broad category of shamanism, but did so through the prism of evolutionary development, both in terms of human physiology and cultural development. Yet by constructing the idea of a shared religious tradition called shamanism and tying it to a particular geographical area, they also imposed an artificial uniformity to a complex sociocultural world. The end product of the guidebook descriptions and associated displays at the Kuntskamera was to create a unified narrative of the peoples of Russia's Asian possessions while simultaneously creating critical cultural distance between Russia and Asia.

Zachary Hoffman concludes this set of articles on visual representations of Asia with his article on political cartoons during the Boxer Rebellion and Russo-Japanese War. A point of emphasis for Hoffman is that both conservative and liberal publications employed ethnic stereotypes, and for the Boxer Rebellion they were remarkably consistent. Europeans engaged in repressing the Boxers were stereotyped according to nationality and were harshly criticized for their violence and lack of civilization. Yet depictions of the Chinese, while sympathetic, were often grotesque caricatures designed to create a sense of primitive 
otherness. Political cartoons of the Japanese in 1904-5, however, were more complicated. The liberal (and anti-war) Russkoe slovo and Iskry tended to portray the Japanese as mostly Western (and therefore only slightly exoticized) and worthy of Russians' respect. But the conservative and nationalistic Novoe vremia characterized the Japanese very much like the Chinese, ape-like and backward, yet also diminutive and with an unhealthy dose of ambition. Thus, whereas both imposed an Asian otherness on China while depicting a superior Russian morality in relation to other European powers, only Russian conservatives did the same with Japan. Liberals seem to have accepted the evolutionary progression of Japan to a state of near-Europeanness.

Taken together, these four articles demonstrate the broad cast of characters involved in helping Russians "see" Asia and its inhabitants. Abbesses and political exiles in Siberia, museum curators at the Kuntskamera, and newspaper satirists and editors in St. Petersburg and Moscow were all part of an imperial project that sought to categorize the peoples within the Russian Empire and those on its eastern borders. The power of imperial imagination was thus quite diffuse and operated in multiple spheres. And if Russian actors were diverse, so too were their subjects, yet, as all these authors point out, the differences among the peoples of Asia were often constructed as evolutionary in nature, plotting each cultural group on a linear civilizational hierarchy with Russians at the top. A final point of emphasis for all four articles is that the Russian imperial construction of Asia was firmly embedded within broader European political and scientific frameworks. The discourses of ethnography and political satire were pan-European, with Russian participants in the late nineteenth and early twentieth centuries reflecting and contributing to understandings of "Asianness." 
Jane F. Hacking is professor of Russian at the University of Utah. She is the author of Coding the Hypothetical (1998). She publishes in the areas of L2 Russian phonology and the development of second language proficiency. In 2017 she was recognized for Outstanding Contribution to the Profession by the American Association of Slavic and East European Languages. E-mail: j.hacking@utah.edu.

Jeffrey S. Hardy is associate professor of history at Brigham Young University. He is the author of The Gulag after Stalin: Redefining Punishment in Khrushchev's Soviet Union (2016), which was awarded honorable mention for the W. Bruce Lincoln Prize by the Association for Slavic, East European, and Eurasian Studies.

E-mail: jeff_hardy@byu.edu.

Matthew P. Romaniello is associate professor of history at Weber State University and editor of The Journal of World History. He is author of Enterprising Empires: Russia and Britain in Eighteenth-Century Russia (2019) and The Elusive Empire: Kazan and the Creation of Russia, 1552-1671 (2012). E-mail: matthewromaniello@weber.edu; ORCID https://orcid.org/0000-0002-5159-764X. 